\title{
The effects of land use types, management practices and slope classes on selected soil physico-chemical properties in Zikre watershed, North-Western Ethiopia
}

\author{
Yihenew G Selassie ${ }^{1}$, Fentanesh Anemut ${ }^{2}$ and Solomon Addisu ${ }^{3 *}$
}

\begin{abstract}
Background: Land degradation is one of the major threats to food security and natural resources conservation Zikre watershed. The objective of the study was to investigate the effects of land use types, management practices and slope classes on soil physico-chemical properties.

Results: Results of the experiment indicated highest mean values of total nitrogen (0.23\%), organic matter (5.01\%) and cation exchange capacity $\left(35.44 \mathrm{cmol}_{(+)} \mathrm{kg}^{-1}\right)$ were recorded under the natural forest and the lowest values of the same $\left(0.12 \%, 2.57 \%\right.$ and $26.08 \mathrm{cmol}_{(+)} \mathrm{kg}^{-1}$, respectively) were registered in crop lands. Available phosphorus content was the highest $(6.18 \mathrm{mg} \mathrm{kg})$ in crop lands and the lowest $\left(1.33 \mathrm{mg} \mathrm{kg}^{-1}\right)$ in grazing lands. Comparing management practices the highest mean values of available phosphorus (18.41 $\mathrm{mg} \mathrm{kg}^{-1}$ ), organic matter (5.88\%) and total nitrogen (0.29\%) were recorded from the cultivated land treated with both manure and soil bund compared to sole soil bund, sole manure and the control plots. Considering the slope classes, the higher mean values of total nitrogen (0.19\%), organic matter (4.49\%) and cation exchange capacity $\left(33.09 \mathrm{cmol}_{(+)} \mathrm{kg}^{1}\right)$ were recorded in the lower slope classes followed by middle $\left(0.17 \%, 3.39 \%\right.$ and $30.58 \mathrm{cmol}_{(+)} \mathrm{kg}^{-1}$, respectively) and upper slope classes $\left(0.14 \%, 2.65 \%\right.$ and $27.36 \mathrm{cmol}_{(+)} \mathrm{kg}^{-1}$, respectively).

Conclusions: To conclude, conversion of forest lands to cultivated and grazing lands had detrimental effects on the soil physico-chemical properties; whereas construction of soil bunds on farm fields and application of manure improve the same under subsistence farming systems.
\end{abstract}

Keyword: Land use type; Land management; Slope class; Soil physico-chemical properties

\section{Background}

Environmental degradation caused by inappropriate land use is a worldwide problem that has attracted attention in sustainable agricultural production systems. Ethiopia is considered to be one of the least developed countries where agriculture had always played a central role in the country's economy. Although agriculture has always been the mainstay of the economy, it is characterized by very low growth rate. The rapidly increasing population has led to a declining availability of cultivable land and a very high

\footnotetext{
* Correspondence: soladd2000@yahoo.com

${ }^{3}$ College of Science and Technology, Environmental Sciences Department, Andhra University, Visakhapatnam, India

Full list of author information is available at the end of the article
}

rate of soil erosion (Abera 2003). It is apparent that soil is one of the most important and determinant factors that strongly affects crop production. Soil is the foundation resource for nearly all land uses, and the most important component of sustainable agriculture (Mulugeta and Karl 2010). Therefore, assessment of soil quality indicators with respect to land use types, management practices and slope classes is useful and primary indicator for sustainable agricultural land management. Understanding the effect of these factors on soil properties is useful for devising land management strategies. The information can also be used to forecast the likely effects of any potential changes in land use types and management practices on soil properties. It is 
apparent that the destruction of vegetative cover can promote soil erosion, which eventually increases the magnitude of soil related constraints to crop production. Generally, a sound understanding of land use and management effects on soil properties provides an opportunity to evaluate sustainability of land use systems (Woldeamlak 2003).

There is increasing awareness that soil nutrient depletion from the agro ecosystem is a very widespread problem and an immediate crop production constraint in Ethiopia (Stoorvogel and Smaling 1990; Stoorvogel et al. 1993). A change in land use, poor soil management, topography of the area and socioeconomic activities can negatively affect the potential use of an area and may ultimately lead to land degradation and loss of productivity. Loss of arable land due to soil degradation is a wide spread phenomenon in the highlands of Ethiopia, which accounts for $45 \%$ of Ethiopian total land area and 66\% of the total land area of Amhara Region (Lakew et al. 2006). Low soil fertility was reported as one of the major factors affecting crop production in west part of Amhara region (Yihenew 2002, 2007). Therefore, the objective of this research was to assess the effects of different land use types, management practices and slope classes on selected soil physico-chemical properties of Zikere watershed, North-western Ethiopia.

\section{Results and discussion}

Land use and slope versus soil physical properties

There was significant difference in percentage of sand, silt and clay contents $(\mathrm{p}<0.05)$ among soils of different

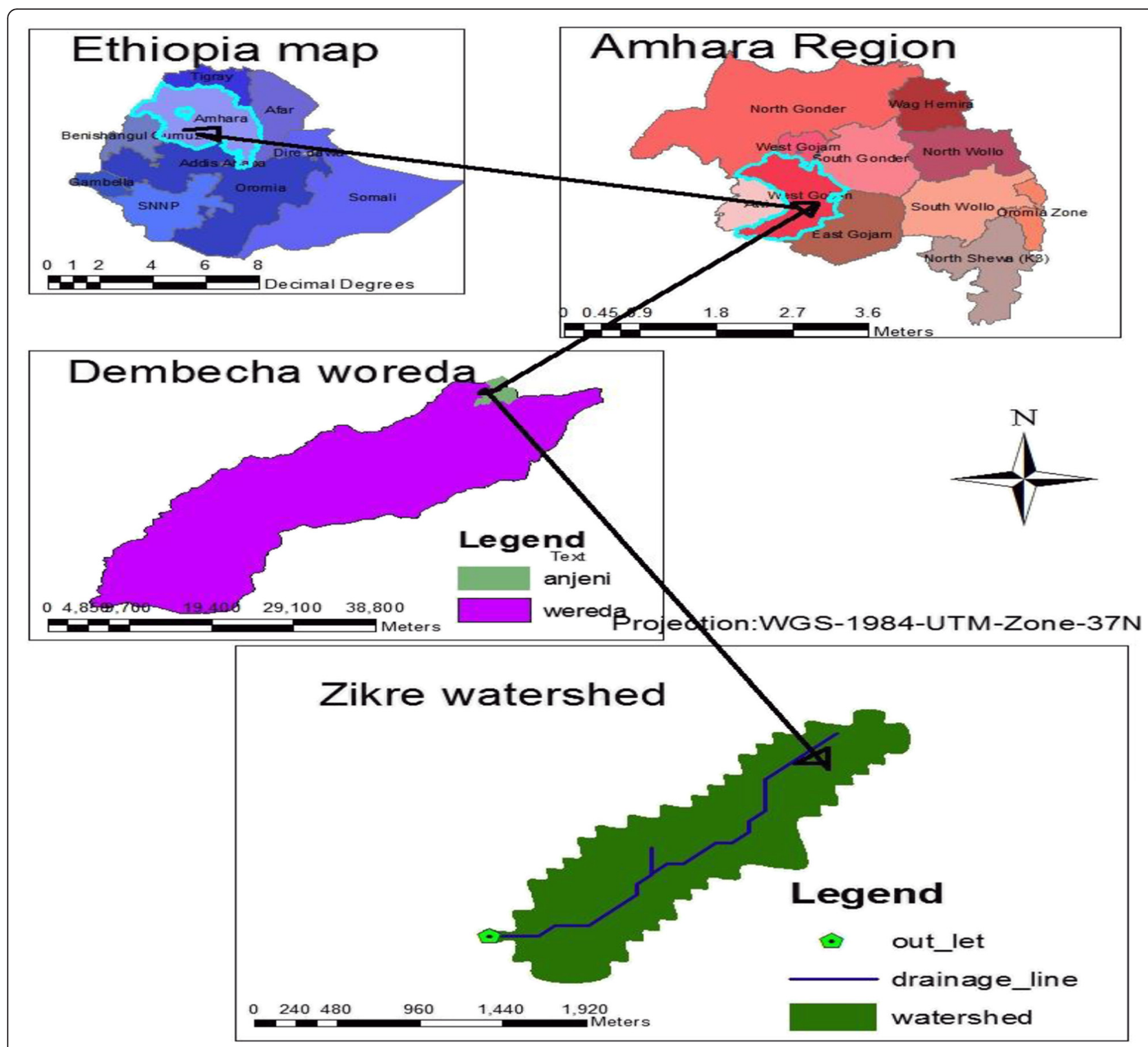

Figure 1 Location map of the study area. 
land use types. The mean value of sand fraction was lowest (18\%) under the natural forest and highest (34.76\%) in grazing lands (Table 1). Soils in natural forest and plantation forest had clay texture while crop and grazing lands had clay loam texture. This could probably be attributed to the selective removal of clay particles by erosion leaving the sand particles in the crop and freely grazed land. Under sparser vegetation covers, the clay fractions are likely to be lost to processes of erosion and migration down the soil profile (Woldeamlak 2003). In unprotected lands, the finer soil particles will be selectively removed by erosion, thereby increasing the proportion of the coarser particles in the soil which leaves more sand particles. In line with this, Mulugeta (2004) and Belayneh (2009) reported that deforestation, farming practices and intensive grazing change soil texture by aggravating soil erosion.

Bulk density was significantly different $(\mathrm{p}<0.05)$ among land use types and slope classes. The mean value of bulk density was lowest $\left(1.05 \mathrm{t} \mathrm{m}^{-3}\right)$ under the natural forest and highest $\left(1.33 \mathrm{t} \mathrm{m}^{-3}\right)$ in grazing land. High bulk density values in grazing land and cultivated land might be due to the result of excessive wet season livestock trampling and continuous shallow depth cultivation and low organic matter input. This result was in line with the works of Islam and Weil (2000), Woldeamlak (2003), Mulugeta
(2004) and Yihenew and Getachew (2013). The reason for the lowest soil bulk density on the forest land as well as in the lower slope position could be due to the higher clay content and accumulation of organic matter. Similarly, less disturbance of the land unlike other land uses could be the other reason.

\section{Land use and slope versus soil chemical properties}

Land use changes from forest to crop land resulted in reduction of soil pH. The highest (6.05) and the lowest (5.44) soil $\mathrm{pH}$ were recorded under the forest and the cultivated lands, respectively (Table 2). According to Mohammed (2003), the soil in high altitude and higher slopes had low $\mathrm{pH}$ values, probably suggesting the washing away of solutes and basic cations from these parts. Continuous cultivation practices, excessive precipitation, steepness of the topography and application of inorganic fertilizer could have attributed as some of the factors which are responsible for the reduction of $\mathrm{pH}$ in the soil. Mohammed (2003) also concluded that the lowest value of $\mathrm{pH}$ under the cultivated land could be due to the depletion of basic cations in crop harvest and leached to streams in runoff generated from accelerated erosions. The other reason could be higher microbial oxidation that produces organic acids, which provide $\mathrm{H}^{+}$to the soil

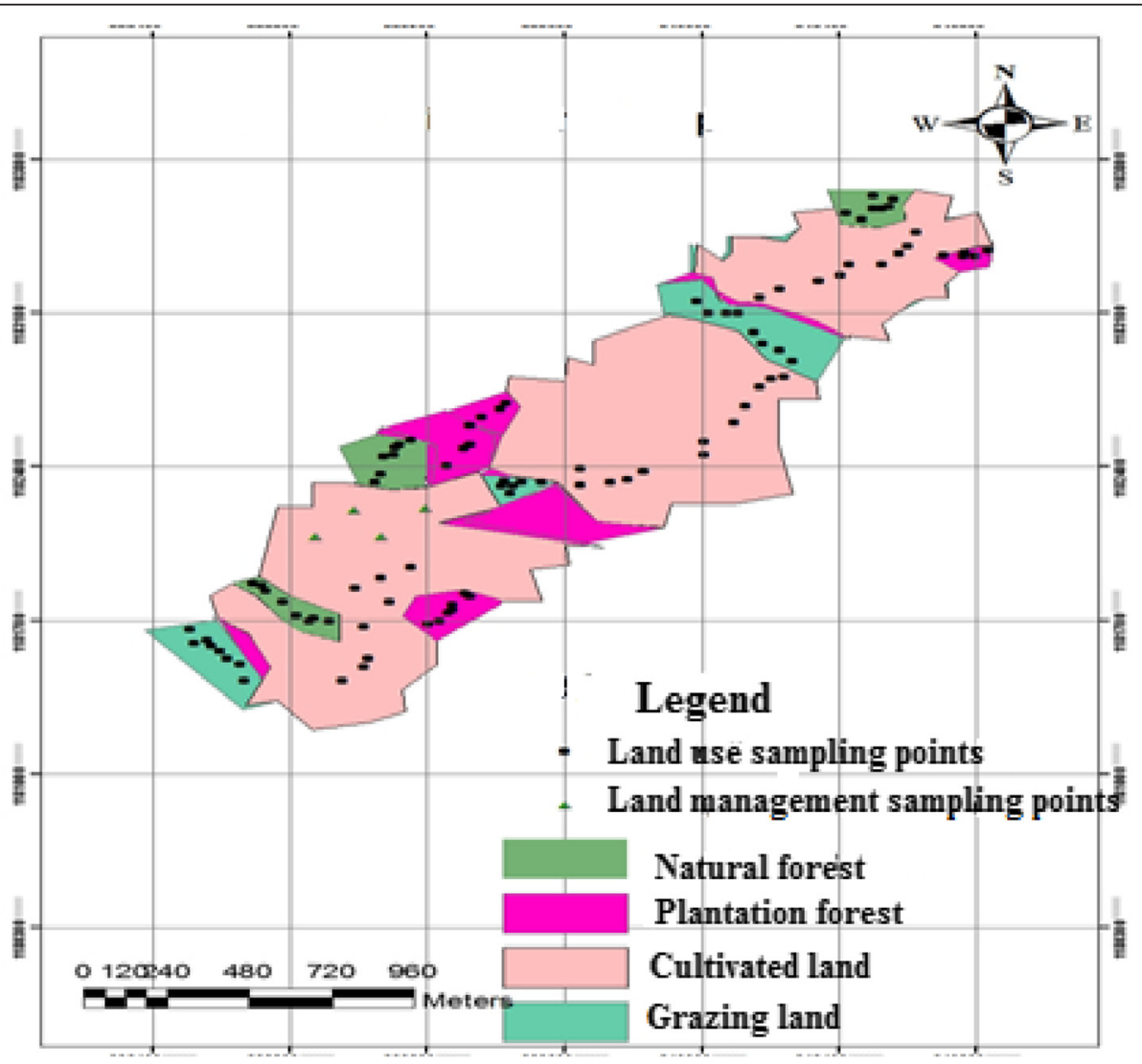

Figure 2 Land use types and sampling points. 
solution and, thereby, lowers soil $\mathrm{pH}$. Generally, the $\mathrm{pH}$ values observed in the study area are within the ranges of strongly acidic to slightly acidic reactions according the rating of Foth and Ellis (1997).

The mean OM was significantly different $(\mathrm{p}<0.05)$ among the land use types and slope classes (Table 2). Soil OM content was highest (5.01\%) under the natural forest land and lowest $(2.57 \%)$ on the cultivated land. The result was in agreement with that of Yihenew and Getachew (2013) who reported that lowest organic carbon was registered in cultivated land and highest in the natural forestland. The mean TN was significantly different among land use types and slope classes $(\mathrm{p}<0.05)$. The average values of TN were highest $(0.23 \%)$ on the natural forest and lowest $(0.12 \%)$ under the cultivated land. The results were similar with the reports of Yihenew and Getachew (2013). The $\mathrm{N}$ contents in the lower slope soils of the forest land were medium; while on cultivated land and grazing lands were low based on classification of Landon (1991).

There was a significant difference of available $P$ (AP) contents among various land uses and slope classes $(\mathrm{p}<0.05)$ (Table 2). The AP content in the cultivated land appeared to be significantly higher than the rest land use types. Hence, the highest $\left(6.18 \mathrm{mg} \mathrm{kg}^{-1}\right)$ and the lowest (1.33 $\mathrm{mg} \mathrm{kg}^{-1}$ ) AP contents were observed under the cultivated and the grazing lands, respectively (Table 2). Similar findings were reported by Gebeyaw (2007) and Woldeamlak (2003). Although the OM content of the cultivated land was lowest, AP content was highest under the cultivated land than the other land use types. This could be due to the application of Diammonium phosphate (DAP) fertilizer on the cultivated land in line with the explanation made by Woldeamlak (2003) and Gebeyaw (2007).

Cation exchange capacity (CEC) values were significantly different among the land use types and slope classes $(\mathrm{p}<0.05)\left(\right.$ Table 2). The highest $\left(35.44 \mathrm{cmol}_{(+)} \mathrm{kg}^{-1}\right)$

Table 1 Selected soil physical properties of different land use type and slope classes

\begin{tabular}{llllll}
\hline Sampling units & $\begin{array}{l}\text { Sand } \\
\mathbf{( \% )}\end{array}$ & $\begin{array}{l}\text { Silt } \\
\mathbf{( \% )}\end{array}$ & $\begin{array}{l}\text { Clay } \\
\mathbf{( \% )}\end{array}$ & $\begin{array}{l}\text { Textural } \\
\text { class }\end{array}$ & $\begin{array}{l}\text { Bd } \\
\mathbf{( t ~ m}^{\mathbf{3}} \mathbf{)}\end{array}$ \\
\hline Land use types & & & & & \\
Natural forest & $18.44^{\mathrm{b}}$ & $32.68^{\mathrm{b}}$ & $48.88^{\mathrm{a}}$ & Clay & $1.05^{\mathrm{d}}$ \\
Crop land & $33.22^{\mathrm{a}}$ & $36.65^{\mathrm{a}}$ & $30.12^{\mathrm{b}}$ & Clay loam & $1.22^{\mathrm{b}}$ \\
Plantation forest & $22.33^{\mathrm{b}}$ & $29.76^{\mathrm{c}}$ & $47.90^{\mathrm{a}}$ & Clay & $1.11^{\mathrm{c}}$ \\
Grazing land & $34.76^{\mathrm{a}}$ & $35.24^{\mathrm{a}}$ & $30.00^{\mathrm{b}}$ & Clay loam & $1.33^{\mathrm{a}}$ \\
Slope classes & & & & & \\
Upper (28\%) & $34.75^{\mathrm{a}}$ & $34.55^{\mathrm{a}}$ & $30.70^{\mathrm{c}}$ & Clay loam & $1.21^{\mathrm{a}}$ \\
Middle (18\%) & $24.77^{\mathrm{b}}$ & $34.45^{\mathrm{a}}$ & $40.79^{\mathrm{b}}$ & Clay & $1.17^{\mathrm{b}}$ \\
Lower (8\%) & $24.30^{\mathrm{b}}$ & $31.75^{\mathrm{b}}$ & $43.95^{\mathrm{a}}$ & Clay & $1.15^{\mathrm{c}}$ \\
\hline
\end{tabular}

Means for land use types and slope classes within a column followed by the same letter are not significantly different from each other at $p<0.05$. and the lowest $\left(26.08 \mathrm{cmol}_{(+)} \mathrm{kg}^{-1}\right)$ values were observed under natural forest and the cultivated lands, respectively. However, cultivated land and plantation forest showed statistically non-significant difference between them. It is a general truth that both clay and colloidal OM have the ability to absorb and hold positively charged ions. Thus, soils containing high clay and OM contents have high CEC. According to Belayneh (2009), land use highly significantly influenced the change in CEC.

\section{Management practices versus soil properties}

The analysis of variance showed the presence of significant difference $(p<0.05)$ in mean value of bulk density (BD) among management practices. The non-managed plots were found to exhibit significantly higher mean value of BD than the managed plots (Table 3). This could be attributed to the presence of significantly higher $\mathrm{OM}$ as a result of conservation measures and manure application. According to Mulugeta and Karl (2010), the non-conserved microwatershed was found to exhibit significantly higher mean value of $\mathrm{BD}$ than the micro-watershed treated with soil and water conservation measures which had been attributed to the presence of significantly higher organic matter as a result of conservation measures. Similar result was reported by Tadele et al. (2013).

There was significant difference in mean value of $\mathrm{pH}(\mathrm{p}<0.05)$ among the treatments (Table 3$)$. The non-managed plot has the lowest $\mathrm{pH}$ value than other treatments. Soil reactions for all the soil samples were moderately acidic to slightly acidic $(5.63-6.36)$. This result was in agreement with results of Alemayhu (2007) for Anjeni catchment who explained that the mean $\mathrm{pH}$ value of both the terraced and the non-terraced farm plots were rated moderately acidic. The same work discussed that the overall acidity situation might have resulted from the moist climatic conditions prevailing in the study areas.

Table 2 The effect of land use systems and slope classes on selected soil chemical properties

\begin{tabular}{llllll}
\hline Sampling units & $\begin{array}{l}\mathbf{p H} \\
\left(\mathbf{H}_{\mathbf{2}} \mathbf{O}\right)\end{array}$ & $\begin{array}{l}\text { TN } \\
\mathbf{( \% )}\end{array}$ & $\begin{array}{l}\mathbf{A P} \\
\left(\mathbf{m g k g}^{-\mathbf{1}}\right)\end{array}$ & $\begin{array}{l}\text { OM } \\
\mathbf{( \% )}\end{array}$ & $\begin{array}{l}\mathbf{C E C} \\
\left(\mathbf{C m o l}{ }_{(+)} \mathbf{~ k g}^{-\mathbf{1}}\right)\end{array}$ \\
\hline Land use type & & & & & \\
Natural forest & $6.05^{\mathrm{a}}$ & $0.23^{\mathrm{a}}$ & $4.40^{\mathrm{b}}$ & $5.01^{\mathrm{a}}$ & $35.44^{\mathrm{a}}$ \\
Crop land & $5.44^{\mathrm{c}}$ & $0.12^{\mathrm{d}}$ & $6.18^{\mathrm{a}}$ & $2.57^{\mathrm{d}}$ & $26.08^{\mathrm{c}}$ \\
Plantation forest & $5.68^{\mathrm{b}}$ & $0.17^{\mathrm{b}}$ & $2.56^{\mathrm{c}}$ & $3.48^{\mathrm{b}}$ & $27.89^{\mathrm{c}}$ \\
Grazing land & $5.65^{\mathrm{b}}$ & $0.15^{\mathrm{c}}$ & $1.33^{\mathrm{d}}$ & $2.98^{\mathrm{c}}$ & $31.97^{\mathrm{b}}$ \\
Slope class & & & & & \\
Upper (28\%) & $5.58^{\mathrm{b}}$ & $0.14^{\mathrm{c}}$ & $3.16^{\mathrm{b}}$ & $2.65^{\mathrm{c}}$ & $27.36^{\mathrm{c}}$ \\
Middle (18\%) & $5.72^{\mathrm{a}}$ & $0.17^{\mathrm{b}}$ & $2.39^{\mathrm{c}}$ & $3.39^{\mathrm{b}}$ & $30.58^{\mathrm{b}}$ \\
Lower (8\%) & $5.80^{\mathrm{b}}$ & $0.19^{\mathrm{a}}$ & $5.30^{\mathrm{a}}$ & $4.49^{\mathrm{a}}$ & $33.09^{\mathrm{a}}$ \\
\hline
\end{tabular}

Means in a column for land use types and slope classes followed by the same letter are not significantly different at $\mathrm{p}<0.05$. 
Soil organic matter (OM) contents between the managed and non-managed plots were also significantly different $(\mathrm{p}<0.05)$ (Table 3). The non-conserved plots had significantly lower mean value of $\mathrm{OM}$ than all other treatments considered in the study. The result agrees with the finding of Tadele et al. (2011). The variations in mean value of OM could have attributed to the effect of management practices implemented and biomass accumulated. However, physical soil and water conservation (SWC) measures complemented with organic manure application raised soil OM content better than soils with only soil bund construction. Mohammed (2003) showed that manure addition had significantly increased the amount of OM level at a nearby watershed called Anjeni. Total nitrogen content was significantly different among land management practices $(\mathrm{p}<0.05)$ (Table 3). Physical SWC measures complemented with manure gave higher TN compared to other measures and the non-conserved lands. Mulugeta and Karl (2010) stated that physical SWC measures stabilized with nitrogen fixing plants have given much higher TN than other biological measures. They also discussed that the non-conserved land had the smallest mean value of $\mathrm{TN}$ compared to the conserved catchment.

The mean values of CEC were highly significantly different $(\mathrm{p}<0.05)$ among land management practices (Table 3). High organic matter and clay contents increase CEC in soils (Yihenew and Getachew 2013). Similarly, Mulugeta and Karl (2010)) supported the idea that high clay soils can hold more exchangeable cations than a low clay containing soils. There was highly significant difference in mean value of AP among the land management practices $(p<0.05)$. The mean value of the same parameter from managed plots was higher than that of the non-managed plot. According to Mulugeta and Karl (2010), AP was significantly different between the conserved and non-conserved fields. The variation was reported to be due to the soil OM content difference.

\section{Conclusions}

From the study, it was possible to conclude that soil physico-chemical properties significantly vary among land use types, land management practices and slope classes. It was apparent that shift in land use types from natural forest to the other land use types had negative effect on soil physical and chemical properties. The overall qualities of the soils under the cultivated land were inferior to soils attributes of the adjacent natural forest, plantation forest and grazing lands. Therefore, integrated land management practices are the most effective ways in reducing soil erosion and increasing soil fertility of cultivated lands.

\section{Methods}

\section{Description of the study area}

The research was carried out in Zikre watershed, located in the highlands of north-western Ethiopia (Figure 1). The area is located at an approximate geographical coordinate

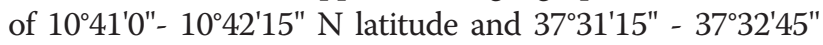
E longitude. The watershed lies at Anjeni kebele (lowest administrative unit in Ethiopia), Dembecha district of West Gojjam Administrative Zone, Amhara National Regional State. It is found $15 \mathrm{~km}$ north of Dembecha town on the rural road leading to Feres Bet town. A perennial river called Zikre starts in the watershed and flows to the Blue Nile. The watershed covers a total land area of 267 ha and it is inhabited by about 2100 people distributed in the watershed, and consists of 345 households. Zikre watershed lies at altitude ranging from 2368 to 2585 m.a.s.l. The land use of the study area includes approximately $3.37 \%$ natural forest, $67.42 \%$ of cultivated land, $4.87 \%$ of plantation forest, $24.34 \%$ of pasture and grazing land. The mean annual rainfall of the areas is about $1834 \mathrm{~mm}$ and the mean annual temperature is $16^{\circ} \mathrm{C}$. The long-term mean annual minimum and maximum temperatures of the area are $9.0^{\circ} \mathrm{C}$ and $23.3^{\circ} \mathrm{C}$, respectively (Alemayhu 2007).

\section{Soil sampling}

A reconnaissance survey was carried out for identifying representative soil sampling plots after which parallel transects were laid along contour lines. Separate composite samples were collected to evaluate the effect of land use types (natural forest, plantation forest, crop land and grazing land), management practices (cultivated land with 9-year manure plus soil bund, cultivated land with 9-year manure, cultivated land with soil bund only and cultivated land without management practices) and slope classes (upper, middle and lower) on soil physicochemical properties (Figure 2). For treatments with soil bunds, soil samples were taken at the center of the two successive structures. Non-conserved plots refer to the

Table 3 The effect of management practices on selected soil physico-chemical properties

\begin{tabular}{|c|c|c|c|c|c|c|}
\hline Management practices & $\mathrm{pH}\left(\mathrm{H}_{2} \mathrm{O}\right)$ & TN (\%) & $A P\left(\mathrm{mg} \mathrm{kg}^{-1}\right)$ & OM (\%) & $\mathrm{CEC}\left(\mathrm{Cmol}_{(+)} \mathrm{kg}^{-1}\right)$ & $\mathrm{Bd}\left(\mathrm{g} \mathrm{cm}^{-3}\right)$ \\
\hline Manure and soil bund & $6.36^{\mathrm{a}}$ & $0.29^{a}$ & $18.41^{a}$ & $5.88^{a}$ & $31.10^{a}$ & $1.14^{c}$ \\
\hline Bund & $5.72^{c}$ & $0.14^{c}$ & $4.91^{\mathrm{C}}$ & $2.77^{c}$ & $29.26^{b}$ & $1.26^{\mathrm{ab}}$ \\
\hline Manure & $6.03^{b}$ & $0.21^{b}$ & $10.13^{b}$ & $4.50^{b}$ & $30.80^{a b}$ & $1.24^{b}$ \\
\hline No manure and no soil bund & $5.63^{c}$ & $0.14^{c}$ & $2.53^{c}$ & $2.63^{c}$ & $25.02^{c}$ & $1.30^{a}$ \\
\hline
\end{tabular}

Means in a column followed by the same letter are not statistically different at $p \leq 0.05$. 
area under cultivation that is found adjacent to the conserved plots that did not receive any soil conservation measure or manure application. Total samples collected for analysis were twelve with four treatments and three replications. All soil samples were bagged, labelled and transported to the laboratory for preparation and analysis.

\section{Soil analysis}

The soil samples were air dried under the shade, ground using pestle \& mortar and sieved to pass through $2 \mathrm{~mm}$ sieve. Soil bulk density was determined using undisturbed core sampling method following the procedures described in Black (1965). Particle size distribution (soil texture) was determined by the hydrometer method (Bouyoucos 1962) Soil pH was determined in a 1:2.5 soil to water suspension following the procedure outlined in Sahelemedhin and Taye (2000). The organic carbon content was analyzed by wet digestion method using the Walkley and Black oxidation method (Walkley and Black 1934). Soil organic matter (OM) content was calculated by multiplying soil organic carbon content by a factor of 1.724. The total nitrogen (TN) content was determined using the Kjeldahl method (Bremner and Mulvaney 1982); while the available phosphorus (AP) was determined following the Olsen procedure (Olsen et al. 1954). The cation exchange capacity (CEC) was determined after extraction of the samples with $1 \mathrm{~N}$ ammonium acetate (Chapman 1965).

\section{Statistical data analysis}

Analysis of variance (ANOVA) was done to determine the presence of significant difference among the treatments. In conditions where there was significant difference, mean comparison was performed with Duncan's multiple range test (DMRT) using SAS software (SAS institute 2002).

\section{Competing interests}

The authors declare that they have no competing interests.

\section{Authors' contributions}

YGS has made substantial contributions in conception design, acquisition of data, interpretation of results and leading the overall activities of the research; FA has been involved in data collection, entry, coding, and analysis. SA contributed in writing, drafting the manuscript, revising it critically for important intellectual content. He has given also the final approval of the version to be published. All authors read and approved the final manuscript.

\section{Acknowledgements}

This study would never be completed without the contribution of many people to whom we would like to express our gratitude. The administrative kebele's development agents, district agricultural officials, local guiders, committee leaders and respondent households in each of the sampling kebeles were indispensable for the successful completion of the field work. We would like also to acknowledge people who contributed their knowledge and time in data collection and entry processes.

\section{Author details}

'Department of Natural Resources Management, College of Agriculture and Environmental Sciences, Bahir Dar University, Bahir Dar, Ethiopia. ${ }^{2}$ Banja District Office of Agriculture, Amhara National Regional State, Awi Zone, Injibara, Ethiopia. ${ }^{3}$ College of Science and Technology, Environmental Sciences Department, Andhra University, Visakhapatnam, India.

Received: 19 November 2014 Accepted: 5 January 2015

Published online: 12 February 2015

\section{References}

Abera B (2003) Factors Influencing the Adoption of Soil Conservation Practices in Northwestern Ethiopia. Discussion Papers No. 37. Institute of Rural Development. University of Goettingen, Germany, pp 229-235

Alemayhu A (2007) Impact of Terrace Development and Management on Soil Properties in Anjeni Area, West Gojjam; M.Sc. Thesis. Addis Ababa University, Ethiopia, $p 70$

Belayneh A (2009) Effect of Land Use/Cover on Selected Soil Physico-Chemical Properties in the Western Part of Mount Guna Area, South Gonder zone, Amhara National Regional State, Ethiopia. M.Sc. Thesis. Mekelle University, Ethiopia, p 130

Black CA (1965) Methods of Soil Analysis. Part I. American Society of Agronomy, Madison, Wisconsin, USA, p 1572

Bouyoucos GJ (1962) Hydrometer method improvement for making particle size analysis of soils. Agronomy 5:179-186

Bremner JM, Mulvaney CS (1982) Total Nitrogen. In: Page AL, Miller RH, Keeney DR (eds) Methods of Soil Analysis. II. Chemical and Microbiological Properties. American Society of Agronomy, Soil Science Society of America, pp 595-624

Chapman HD (1965) Cation Exchange Capacity. In: Black CA, Ensminger LE, Clark FE (eds) Methods of Soil Analysis, vol 9. Agronomy inc, Madison, Wisconsin, pp 891-901

Foth HD, Ellis BG (1997) Soil Fertility, 2nd edn. Lewis CRC Press, USA, p 290

Gebeyaw T (2007) Soil Fertility Status as Influenced by Different Land Uses in Maybar Areas of South Wello Zone, North Ethiopia. M.Sc. Thesis. Haramaya University, Ethiopia, p 71

Islam KR, Weil RR (2000) Land use effects on soil quality in a tropical forest ecosystem of Bangladesh. Agric Ecosystems Environ 79:9-16, http://dx.doi. org/10.1016/50167-8809(99)00145-0

Lakew D, Menale K, Benin S, Pende J (2006) Land Degradation and Strategies for Sustainable Development in the Ethiopian High Lands: Amhara Region, Socioeconomic and Policy Research Working Paper 32. ILRI, Nairobi, Kenya, p 14

Landon JR (1991) Booker Tropical Soil Manual: A Hand Book for Soil Survey and Agricultural Land Evaluation with Tropics and Subtropics. Longman scientific and technical, Essex, New York

Mohammed S (2003) The Effect of Organic Matter on Runoff, Soil Loss and Crop Yield at Anjeni, West Gojjam. M.Sc. thesis. Alemaya University, Ethiopia

Mulugeta L (2004) Effects of Land Use Changes on Soil Quality and Native Flora Degradation and Restoration in the Highlands of Ethiopia: Implication for Sustainable Land Management. PhD Dissertation, ISSN 1401-6230, ISBN 91-576-6540-0. Presented to Swedish University of Agricultural Sciences, Uppsala., pp 31-44

Mulugeta D, Karl S (2010) Assessment of integrated soil and water conservation measures on key soil properties in south Gondar, north-western Highlands of Ethiopia. J Soil Sci Environ Manage 1(7):164-176

Olsen SR, Cole CV, Watanable FS, Dean LA (1954) Estimation of available phosphorus in soil by extraction with sodium bicarbonate. USDA Circular 939(1):19

Sahelemedhin S, Taye B (2000) Procedures for Soil and Plant Analysis. National Soil Research Center, EARO, technical paper No.74, Addis Ababa, Ethiopia

SAS Institute (2002) A Business Unit of SAS. SAS Institute Inc, Cary, NC. 2751. USA

Stoorvogel JJ, Smaling EMA (1990) Assessment of soil nutrient depletion in sub-Sahara Africa: Rep. no. 28. Vol. 1-4. Winand Staring Ctr, Wageningen, pp 1983-2000

Stoorvogel J, Smaling E, Janssen B (1993) Calculating soil nutrient balances in Africa at different scales. Fertilizer Res 35:227-235

Tadele A, Yihenew GS, Mitiku H, Yamoh C (2011) Effect of soil and water conservation measures on selected soil physical and chemica properties and Barley (Hordeum spp.) Yield. J Environ Sci Eng 5:1488-1493

Tadele A, Aemro T, Yihenew GS, Birru Y, Wolfgramm B, Hurni H (2013) Soil properties and crop yields along the Terraces and toposequece of Anjeni watershed, Central Highlands of Ethiopia. J Agric Sci 5:2 
Walkley A, Black CA (1934) An examination of the digestion method for determining soil organic matter and a proposed modification of the chromic acid titration method. Soil Sci 37:29-38

Woldeamlak B (2003) Towards Integrated Watershed Management in Highland Ethiopia: the Chemoga watershed case study. Tropical Resource Management Papers 44, Wageningen University

Yihenew GS (2002) Selected chemical and physical characteristics of soils of Adet Research Center and its Testing Sites in Northwestern Ethiopia. Ethiop J Nat Resour 4:199-215

Yihenew GS (2007) Evaluation of nitrogen and phosphorus as yield-limiting nutrients for Maize grown on Alfisols of Western Amhara. Ethiop J Nat Resour 9(1):155-170

Yihenew GS, Getachew A (2013) Effects of different land use systems on selected physico- chemical properties of soils in Northwestern Ethiopia. J Agric Sci 5:114-117

Submit your manuscript to a SpringerOpen ${ }^{\circ}$ journal and benefit from:

- Convenient online submission

- Rigorous peer review

- Immediate publication on acceptance

Open access: articles freely available online

- High visibility within the field

- Retaining the copyright to your article

Submit your next manuscript at $>$ springeropen.com 